\title{
Electrode Contact Device
}

National Cancer Institute

\section{Source}

National Cancer Institute. Electrode Contact Device. NCI Thesaurus. Code C50351.

A connector on a device designed to couple with an electrode. 